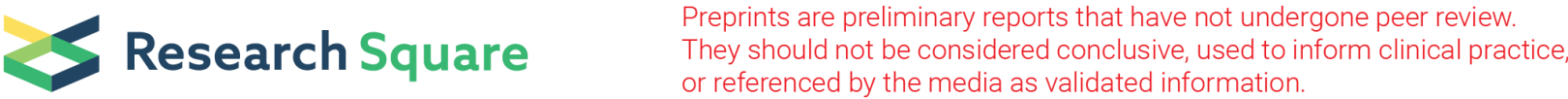

\section{Analysis of characteristics of workers with occupational benzene poisoning in Jiangsu province,2006-2018}

\section{Guangzhi Yang}

Southeast University https://orcid.org/0000-0003-4024-2381

\section{WANG Huimin}

Southeast University

\section{WANG Boshen}

Southeast University

\section{HAN Lei}

Jiangsu Province Center for Disease Control and Prevention

ZHU Baoli ( $\nabla$ zhubl@jscdc.cn )

Jiangsu Province Center for Disease Control and Prevention

\section{Short report}

Keywords: occupational disease, occupational benzene poisoning, benzene induced leukemia

Posted Date: July 28th, 2020

DOl: https://doi.org/10.21203/rs.3.rs-48704/v1

License: (c) (1) This work is licensed under a Creative Commons Attribution 4.0 International License. Read Full License 


\section{Abstract}

Objective To investigate the characteristics of workers with occupational benzene poisoning in Jiangsu Province during 2006-2018, find out the susceptible population of occupational benzene poisoning and provide some evidence for establishing some exposure standards for workers.

Methods Questionnaire is the tool that we adopt to collect basic information of workers. Benzene detector is applied to detect the concentration of benzene in the working environments. Statistical description and analysis was conducted to analyze the prevalence of occupational benzene poisoning in Jiangsu Province during 2006-2018.

Results The number of cases of occupational benzene poisoning in these years was 145, and 28 of them were diagnosed with benzene induced leukemia; the patients mainly worked in manufacturing industry $\llbracket 89.7 \% \bigotimes$; most of cases were distributed in small factories $₫ 43.4 \% \bigotimes$ and private companies $₫ 46.2 \% \bigotimes$. Male workers took a major part in the cases of acute benzene poisoning $₫ 80 \% \rrbracket$ while female workers had a higher proportion of the chronic benzene poisoning $₫ 65 \% \bigotimes$. Most cases were distributed in the 30-49 age group ( $80 \%$ ). There was no evident differences among these seniority groups, most of the cases were in the working age of 1-19 years old $882.9 \% \rrbracket$; concentration of benzene of chronic benzene poisoning workers were mostly under $0.6 \mathrm{mg} / \mathrm{m}^{3} \otimes 40 \% \bigotimes$.

Conclusions The departments of occupational disease prevention should heighten the benzene surveillance of small-scale private companies in manufacturing industry, regular physical examination and health education should be conducted in the workers of low concentration of benzene exposure, safety protection measures should be taken to reduce the incidence of occupational poisoning.

\section{Background}

Jiangsu province is one of powerful economic and industrial provinces in China. Economic growth in the central Jiangsu fluctuated while it held stable in the southern Jiangsu ${ }^{[1]}$. A great number of workers from other provinces come into Jiangsu province for living work. With the development of industry, the number of enterprises and workers exposed to benzene is increasing. Benzene is a chemical substance commonly used in industry and is harmful to human body. After entering human body, benzene can lead to lipid peroxidation in biofilms through physiological metabolism, thus causing teratological, carcinogenic and other changes. It's reported that there is an association between ambient benzene and risk of hematologic malignancies ${ }^{[2]}$. Studies have shown that the expression of $m-R N A$ in the blood of workers exposed to benzene for a long time is different from that of normal people ${ }^{[3]}$. Some people even take advantage of the toxicity of benzene to body to commit suicide ${ }^{[4]}$. Occupational benzene poisoning is a common occupational disease in the industrial factories of big cities ${ }^{[5]}$, which can be classified as acute occupational benzene poisoning and chronic occupational benzene poisoning ${ }^{[6]}$. Acute toxicity of benzene is mainly reflected in human skin, respiration and nervous system ${ }^{[7]}$. A research conducted in population by Fudan University and the University of Toronto shows that benzene exposure has linked 
with a variety of blood system diseases ${ }^{[8]}$. Benzene - induced leukemia is one of the most serious chronic benzene poisoning diseases. The pathogenesis of benzene-induced leukemia is related to the genetic changes of benzene-induced hematopoietic stem cells ${ }^{[9]}$. In response to the "2030" health plan of China and achieve the goal of "Health Jiangsu 2030 Planning" as soon as possible, the statistical description and statistical analysis of the cases of occupational benzene poisoning in 2006-2018 was conducted to understand the period prevalence of benzene workers in Jiangsu province, so as to determine the risk factors, improve the level of management of occupational benzene poisoning prevention and formulate the corresponding prevention measures.

\section{Subjects And Methods}

Target subjects: Patients with occupational benzene poisoning exposed to benzene in various industries in Jiangsu Province from 2006 to 2018.

Methods: Questionnaire is the tool that we adopt to collect basic information of workers. Benzene detector is applied to detect the concentration of benzene in the working environments. The cases of occupational benzene poisoning of workers exposed to benzene from 2006 to 2018 were statistically described and analyzed. Occupational benzene poisoning cases were classified as acute benzene poisoning, chronic benzene poisoning and benzene - induced leukemia. These cases were described and analyzed in terms of the variation with time, industry distribution, regional distribution, gender, age and working years.

\section{Results}

Basic Information: The occupational benzene poisoning data reported in the province from 2006 to 2018 showed that the incidence was relatively higher in 2013, with 21 cases, accounting for $14.48 \%$ of the total reported cases. A total of 145 cases of occupational benzene poisoning were reported in the past 13 years, including 140 cases of occupational chronic benzene poisoning, accounting for $96.55 \%$ of the total reported cases, 5 cases of acute benzene poisoning and 28 cases of benzene-induced leukemia. In terms of the cases of benzene-induced leukemia, 28 cases were reported during 13 years, mainly distributed in 2007, 2013 and 2015, 11 cases in total, accounting for 39.29\% of the total reported cases(Table 1, Figure 1 ). It is apparent from figure 1 that a great majority of cases were found in 2013 . The number of cases fluctuated by year and it has no evident tendency of growth or decrease. 


\begin{tabular}{|llll|}
\hline \multicolumn{2}{|l|}{ Table 1} & The cases of benzene poisoning distributed in time & \\
\hline Year & $\begin{array}{l}\text { acute occupational benzene } \\
\text { poisoning }\end{array}$ & $\begin{array}{l}\text { chronic occupational benzene } \\
\text { poisoning }\end{array}$ & $\begin{array}{l}\text { benzene-induced } \\
\text { leukemia }\end{array}$ \\
\hline 2005 & 0 & 2 & 0 \\
\hline 2006 & 0 & 6 & 0 \\
\hline 2007 & 0 & 11 & 6 \\
\hline 2008 & 0 & 7 & 2 \\
\hline 2009 & 0 & 9 & 1 \\
\hline 2010 & 1 & 11 & 1 \\
\hline 2011 & 0 & 10 & 0 \\
\hline 2012 & 0 & 11 & 3 \\
\hline 2013 & 1 & 20 & 5 \\
\hline 2014 & 0 & 12 & 2 \\
\hline 2015 & 0 & 10 & 5 \\
\hline 2016 & 0 & 18 & 1 \\
\hline 2017 & 1 & 9 & 1 \\
\hline 2018 & 2 & 4 & 1 \\
\hline Total & 5 & 140 & 28 \\
\hline
\end{tabular}

1. Industry distribution: The data from 2006-2018 report of occupational benzene poisoning and benzene leukemia indicates that most of the cases were found in the manufacturing, the occupational benzene poisoning patients accounted for $89.7 \%$ of the total cases, chronic benzene poisoning patients accounted for $90.7 \%$ of the total cases, benzene-induced leukemia accounts for $85.7 \%$ of the total cases, other cases were distributed respectively in leasing and business services, construction, retail trade, transportation, warehousing and postal service, accommodation and catering industry and public management, entertainment and social organization. 


\begin{tabular}{|c|c|c|c|}
\hline industry & $\begin{array}{l}\text { acute occupational } \\
\text { benzene poisoning }\end{array}$ & $\begin{array}{l}\text { chronic occupational } \\
\text { benzene poisoning }\end{array}$ & $\begin{array}{l}\text { benzene-induced } \\
\text { leukemia }\end{array}$ \\
\hline agriculture & 0 & 1 & 0 \\
\hline mining industry & 0 & 0 & 1 \\
\hline $\begin{array}{l}\text { manufacturing } \\
\text { industry }\end{array}$ & 3 & 127 & 24 \\
\hline $\begin{array}{l}\text { construction } \\
\text { industry }\end{array}$ & 1 & 1 & 1 \\
\hline retail trade & 0 & 2 & 1 \\
\hline transportation & 0 & 1 & 1 \\
\hline $\begin{array}{l}\text { hotel and catering } \\
\text { sectors }\end{array}$ & 0 & 1 & 0 \\
\hline $\begin{array}{l}\text { leasing and } \\
\text { business service }\end{array}$ & 1 & 5 & 0 \\
\hline social organization & 0 & 1 & 0 \\
\hline uncertain & 0 & 1 & 0 \\
\hline total & 5 & 140 & 28 \\
\hline
\end{tabular}

2. The distribution of enterprise scale and economic type : The cases of occupational benzene poisoning and benzene-induced leukemia diagnosed in Jiangsu Province from 2006 to 2018 were mainly concentrated in small-scale enterprises. There were 40 cases of chronic benzene poisoning and 5 cases of benzene-induced leukemia. In large-scale enterprises, there were 28 cases of chronic benzene poisoning, 1 case of acute benzene poisoning and 2 cases of benzene-induced leukemia. There were only 2 cases of chronic benzene poisoning and 1 case of benzene-induced leukemia in tiny enterprises. The information of ten cases of chronic benzene poisoning and one case of acute benzene poisoning is unknown. (Table 3, Figure 2)

Divided by economic type, cases are mainly concentrated in private enterprises, state-owned enterprises and foreign enterprises, among which private enterprises account for a relatively high proportion. Benzene poisoning patients in private enterprises account for $44.2 \%$ of the total cases of chronic benzene poisoning, benzene-induced leukemia accounts for up to $57.1 \%$ of the total cases, and all acute benzene poisoning cases were found in private enterprises except for one unknown case. The number of chronic benzene poisoning cases in state-owned enterprises, foreign enterprises and collective enterprises is 38 , 34 and 5 respectively. Among the other cases of benzene-induced leukemia, 5 occurred in foreign businesses, 4 in state-owned enterprises, 2 in collective enterprises, and 1 unknown. (Table 4, Figure 3) 


\begin{tabular}{|llll|}
\hline \multicolumn{4}{|l|}{ Table 3 The cases of benzene poisoning distributed in firm size of industry } \\
\begin{tabular}{|l} 
firm size of \\
industry
\end{tabular} & $\begin{array}{l}\text { acute occupational benzene } \\
\text { poisoning }\end{array}$ & $\begin{array}{l}\text { chronic occupational } \\
\text { benzene poisoning }\end{array}$ & $\begin{array}{l}\text { benzene-induced } \\
\text { leukemia }\end{array}$ \\
\hline large & 1 & 28 & 2 \\
\hline middle & 0 & 40 & 5 \\
small & 3 & 60 & 20 \\
tiny & 0 & 2 & 1 \\
uncertain & 1 & 10 & 0 \\
\hline total & 5 & 140 & 28 \\
\hline
\end{tabular}

Table 4 The cases of benzene poisoning distributed in economic type of industry

\begin{tabular}{|llll|}
$\begin{array}{l}\text { economic } \\
\text { type }\end{array}$ & $\begin{array}{l}\text { acute occupational benzene } \\
\text { poisoning }\end{array}$ & $\begin{array}{l}\text { chronic occupational benzene } \\
\text { poisoning }\end{array}$ & $\begin{array}{l}\text { benzene-induced } \\
\text { leukemia }\end{array}$ \\
\hline state-owned & 0 & 38 & 3 \\
\hline collective & 0 & 5 & 2 \\
\hline private & 5 & 62 & 16 \\
\hline $\begin{array}{l}\text { foreign } \\
\text { merchant }\end{array}$ & 0 & 34 & 6 \\
\hline uncertain & 0 & 1 & 1 \\
total & 5 & 140 & 28 \\
\hline
\end{tabular}

3. Distribution of gender, age and length of exposure: Among the occupational benzene poisoning cases in Jiangsu province from 2006 to 2018, the cases of acute benzene poisoning was mainly male with 4 cases, accounting for $80 \%$ of the total cases, while the cases of chronic benzene poisoning was mainly female with 91 cases, accounting for $65 \%$ of the total cases. The number of male and female patients with benzene-induced leukemia was similar, 16 and 12 respectively. $ه$ Table 5区

The age of occupational benzene poisoning patients was mainly distributed in the age group of 30-49 years old, and the number of patients accounted for $80 \%$. This age group has a higher incidence of

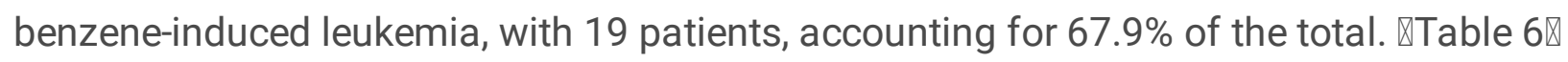

Among the cases of benzene-induced leukemia in Jiangsu province from 2006 to 2018 , workers with 119 year has the highest percentage of length of service of benzene poisoning patients, accounting for $82.9 \%$ of the total, cases of acute benzene poisoning were all found in the workers with a contact length of less than nine years. The cases of chronic benzene poisoning mainly concentrated in workers with a contact length of 1-19 years, with 111 patients, accounting for $79.3 \%$ of the total cases. In addition to 2 
patients of benzene-induced leukemia with the working age of 30-34 years, the remaining cases were all distributed in workers with a working age of 1-24 years, especially in workers with a working age of 1-14 years, with 21 cases, accounting for $75 \%$ of the total cases.(Table 7, Figure 4)

\begin{tabular}{|lllll|}
\hline Table 5 & The cases of benzene poisoning distributed in gender & \\
\hline gender & $\begin{array}{l}\text { acute occupational benzene } \\
\text { poisoning }\end{array}$ & $\begin{array}{l}\text { chronic occupational benzene } \\
\text { poisoning }\end{array}$ & $\begin{array}{l}\text { benzene-induced } \\
\text { leukemia }\end{array}$ \\
\hline male & 4 & 49 & 16 \\
\hline female & 1 & 91 & 12 \\
\hline total & 5 & 140 & 28 \\
\hline Table 6 & The cases of benzene poisoning & distributed in age & \\
\hline age & $\begin{array}{l}\text { acute occupational benzene } \\
\text { poisoning }\end{array}$ & $\begin{array}{l}\text { chronic occupational benzene } \\
\text { poisoning }\end{array}$ & $\begin{array}{l}\text { benzene-induced } \\
\text { leukemia }\end{array}$ \\
\hline$\leq 19$ & 0 & 0 & 0 \\
\hline $20 \varangle 29$ & 0 & 10 & 1 \\
\hline $30 \varangle 39$ & 2 & 39 & 9 \\
\hline $40 \varangle 49$ & 2 & 73 & 10 \\
\hline $50 \varangle 59$ & 1 & 17 & 4 \\
\hline$\geq 60$ & 0 & 1 & 4 \\
\hline total & 5 & 140 & 28 \\
\hline
\end{tabular}




\begin{tabular}{|c|c|c|c|}
\hline $\begin{array}{l}\text { working } \\
\text { years }\end{array}$ & $\begin{array}{l}\text { acute occupational benzene } \\
\text { poisoning }\end{array}$ & $\begin{array}{l}\text { chronic occupational benzene } \\
\text { poisoning }\end{array}$ & $\begin{array}{l}\text { benzene-induced } \\
\text { leukemia }\end{array}$ \\
\hline$<1$ & 1 & 6 & 0 \\
\hline $1 \rrbracket 3$ & 2 & 25 & 7 \\
\hline $4 \rrbracket 6$ & 1 & 27 & 5 \\
\hline $7 \otimes 9$ & 1 & 20 & 4 \\
\hline $10 \otimes 14$ & 0 & 19 & 5 \\
\hline $15 \rrbracket 19$ & 0 & 20 & 3 \\
\hline $20 \rrbracket 24$ & 0 & 14 & 2 \\
\hline $25 \rrbracket 29$ & 0 & 7 & 0 \\
\hline $30 \rrbracket 34$ & 0 & 1 & 2 \\
\hline$\geq 35$ & 0 & 1 & 0 \\
\hline total & 5 & 140 & 28 \\
\hline
\end{tabular}

4. Distribution of contact concentration: According to the data of occupational benzene poisoning from 2006 to 2018, the exposure concentration of acute benzene poisoning patients is unknown. Among 140 patients with chronic benzene poisoning, the contact concentration of 48 patients is unknown, and the benzene exposure concentration of 56 patients is less than $0.6 \mathrm{mg} / \mathrm{m}^{3}$, accounting for $40 \%$ of the total. The number of cases in 1 to $3 \mathrm{mg} / \mathrm{m}^{3}$ was relatively higher, with 19 people, accounting for $13.6 \%$ of the total. There were 6,4 and 7 people with contact concentration of $0.6-1 \mathrm{mg} / \mathrm{m}^{3}, 3-6 \mathrm{mg} / \mathrm{m}^{3}$ and more than $6 \mathrm{mg} / \mathrm{m}^{3}$ respectively. The reported data of benzene-induced leukemia from 2006 to 2018 showed that in addition to 7 patients with unknown exposure concentration, the most patients with exposure concentration below $0.6 \mathrm{mg} / \mathrm{m}^{3}$ were 6 patients, 5 patients with exposure concentration above $0.6 \mathrm{mg} / \mathrm{m}^{3}$ and $6 \mathrm{mg} / \mathrm{m}^{3}$, and 3 and 1 patients with exposure concentration between 1 and $3 \mathrm{mg} / \mathrm{m}^{3}$ and 3 and 6 $\mathrm{mg} / \mathrm{m}^{3}$ respectively. 
Table 8 The cases of benzene poisoning distributed in working years

\begin{tabular}{|c|c|c|c|}
\hline $\begin{array}{l}\text { Contact } \\
\text { concentration } \\
\rrbracket \mathrm{mg} / \mathrm{m}^{3} \rrbracket\end{array}$ & $\begin{array}{l}\text { acute occupational } \\
\text { benzene poisoning }\end{array}$ & $\begin{array}{l}\text { chronic occupational } \\
\text { benzene poisoning }\end{array}$ & $\begin{array}{l}\text { benzene-induced } \\
\text { leukemia }\end{array}$ \\
\hline$\otimes 0.6$ & 0 & 56 & 7 \\
\hline $0.6 \leq \mathrm{N} \otimes 1$ & 0 & 6 & 5 \\
\hline $1 \leq \mathrm{N} \varangle 3$ & 0 & 19 & 3 \\
\hline $3 \leq N \rrbracket 6$ & 0 & 4 & 1 \\
\hline$\geq 6$ & 0 & 7 & 5 \\
\hline 吅 & 5 & 48 & 7 \\
\hline total & 5 & 140 & 28 \\
\hline
\end{tabular}

\section{Discussion}

According to the data of occupational benzene poisoning from 2006 to 2018, the majority of occupational benzene poisoning patients are chronic benzene poisoning patients, because the benzene exposure level of most benzene industry will not lead to acute benzene poisoning of benzene workers. The number of people with occupational benzene poisoning presents the downward trend after first growth, verifies that benzene industry of our country has developed rapidly while benzene protection regulations and measures fail to meet the requirements of healthy standard. Some enterprises lacked developed public health protection measures and racked their brains to escape regulatory. The concentration of some benzene enterprises is higher than benzene concentration limit ${ }^{[10]}$. The reduction of cases in the later period should be attributed to the specialization of occupational disease classification and the strengthening of relevant protection .

This research indicates that occupational benzene poisoning cases are mainly distributed in the manufacturing industry, because people work with the chemical raw material and chemical products of manufacturing industry, computer, communication and other electronic equipment manufacturing industry and special equipment manufacturing industry have more exposure to benzene, which is similar to the research results of other countries ${ }^{[11]}$. Small and medium-sized enterprises and private enterprises do not have developed health protection measures, and many enterprises fail to set up an excellent occupational health monitoring system. Therefore, cases are mostly distributed in small scale and private enterprises in the distribution of enterprise size and economic type. Most of the occupations of patients with acute benzene poisoning are the jobs of painting in the chemical industry or in the manufacturing industry ${ }^{[12]}$. And the workers in these industries are mainly male workers. With regard to chronic benzene poisoning, the number of female patients is higher than that of male patients. The chronic benzene poisoning industry is mainly distributed in manufacturing textile, dyeing and shoe factory, and these factories mainly hire female workers. Compared with men, women are more vulnerable to the threat of 
benzene because of their difference in physiological mechanism and anatomy. Kuang conducted an analysis and proposed that individual susceptibility exists in the cases of chronic benzene poisoning ${ }^{[13]}$. And these can explain the distribution of the gender differences of occupational benzene poisoning patients reasonably.

The main concentration of benzene exposure in patients with chronic benzene poisoning is at a low level, because the concentration of benzene exposure in most enterprises is at a low level. Besides, the white blood cell count of workers working in an environment with low concentration of benzene for a long time will be significantly reduced.

Therefore, regarding to the prevention and treatment of occupational benzene poisoning, emphasis should be placed on the manufacturing industry. The industrial structure of benzene related enterprises in this province should be adjusted, and the processes, methods and technologies with serious occupational hazards should be eliminated as soon as possible. Specific industrial region should be built, standardized management should be implemented and policies related to taxation and loans should be implemented. Benzene related family workshop enterprises and small and micro enterprises should be encouraged to enter the specific region for production, actively developing towards standardization and scale, and constantly promoting industrial technology upgrading. Workers exposed to benzene at low concentrations should be protected, and the detection of relevant biomarkers can early detect patients with chronic occupational disease poisoning ${ }^{[14]}$. Risk managers can use the four-step health risk assessment method to assess the risk of benzene exposure so as to obtain accurate information ${ }^{[15]}$. Prepost training should be provided for benzene workers, and regular training should be provided especially when the production process is changed or the post is transferred. These measures can popularize the prevention and control of benzene work's harm to the organism.

\section{Declarations}

\section{Ethics approval and consent to participate}

Not applicable

\section{Consent for publication}

Not applicable

\section{Availability of data and materials}

All data generated or analysed during this study are included in this published article.

\section{Competing interests}

The authors declare that they have no competing interests 


\section{Funding}

[Fund program] :Jiangsu Province's Outstanding Medical Academic Leader program(CXTDA2017029)

\section{Authors' contributions}

$\mathrm{HL}$ and ZBL has made substantial contributions to the conception and design of the work and the acquisition; WBS is responsible for analysis of data and the creation of new software used in the work; YGZ and WHM has drafted the work and substantively revised it, and YGZ was a major contributor in writing the manuscript. All authors read and approved the final manuscript.

\section{Acknowledgements}

Not applicable

\section{References}

1. Wang Shijin, et al. Coordinated development of economic growth and ecological efficiency in Jiangsu, China.[J]. Environmental science and pollution research international,2020.

2. Lauren R. Teras,et al. Residential ambient benzene exposure in the United States and subsequent risk of hematologic malignancies[J]. International Journal of Cancer,2019,145(10).

3. Liu Y, et al. Analysis of plasma microRNA expression profiles in a Chinese population occupationally exposed to benzene and in a population with chronic benzene poisoning[J]. Journal of Thoracic Disease, 2016. 8(3): p. 403-414.

4. Pouwels $\mathrm{S}$, et al. Thoracic empyema and pectoral abscess resulting from attempting suicide by injection of benzene in the pleural cavity[R]. Respiratory Medicine Case Reports, 2018. 24: p. 74-76.

5. Lin QH,et al. Epidemiological study of occupational diseases in Guangzhou City, China in 2001 2010[J]. Zhonghua Lao Dong Wei Sheng Zhi Ye Bing Za Zhi, 2012. 30(10): p. 759-62.

6. Bahadar, H., et al., The molecular mechanisms of liver and islets of Langerhans toxicity by benzene and its metabolite hydroquinone in vivo and in vitro. Toxicol Mech Methods, 2015. 25(8): p. 628-36.

7. Avis SP, Hutton CJ. Acute benzene poisoning: a report of three fatalities[J]. J Forensic Sci, 1993. 38(3): p. 599-602.

8. Gross SA, et al. Shanghai Health Study (2001-2009): What was learned about benzene health effects? Critical Reviews in Toxicology[J], 2018. 48(3): p. 217-251.

9. McHale $\mathrm{CM}$, et al. Current understanding of the mechanism of benzene-induced leukemia in humans: implications for risk assessment[J]. Carcinogenesis, 2012. 33(2): p. 240-52.

10. Li G,et al. Progress of epidemiological and molecular epidemiological studies on benzene in China[J]. Ann N Y Acad Sci, 2006. 1076: p. 800-9.

11. Fay M, et al. toxicological profile for xylene[J]. ATSDR. 1995. 
12. Wang HQ, et al. Characterization of severe acute occupational poisoning accidents related to organic solvents in China between 1989 and 2003[J]. Zhonghua Lao Dong Wei Sheng Zhi Ye Bing Za Zhi 2006, 24 (12), 720-2.

13. Kuang, S. and W. Liang, Clinical analysis of 43 cases of chronic benzene poisoning. Chem Biol Interact, 2005. 153-154: p. 129-35.

14. Kuang $S$, et al. Clinical analysis of 43 cases of chronic benzene poisoning[J]. Chem Biol Interact, 2005. 153-154: p. 129-35.

15. Zhang Q, et al. Occupational Health Risk Assessment for Workers Exposed to Benzene in Styrene Unit[J]. Aebmr Adv Econ 2018, 66, 447-452.

\section{Figures}

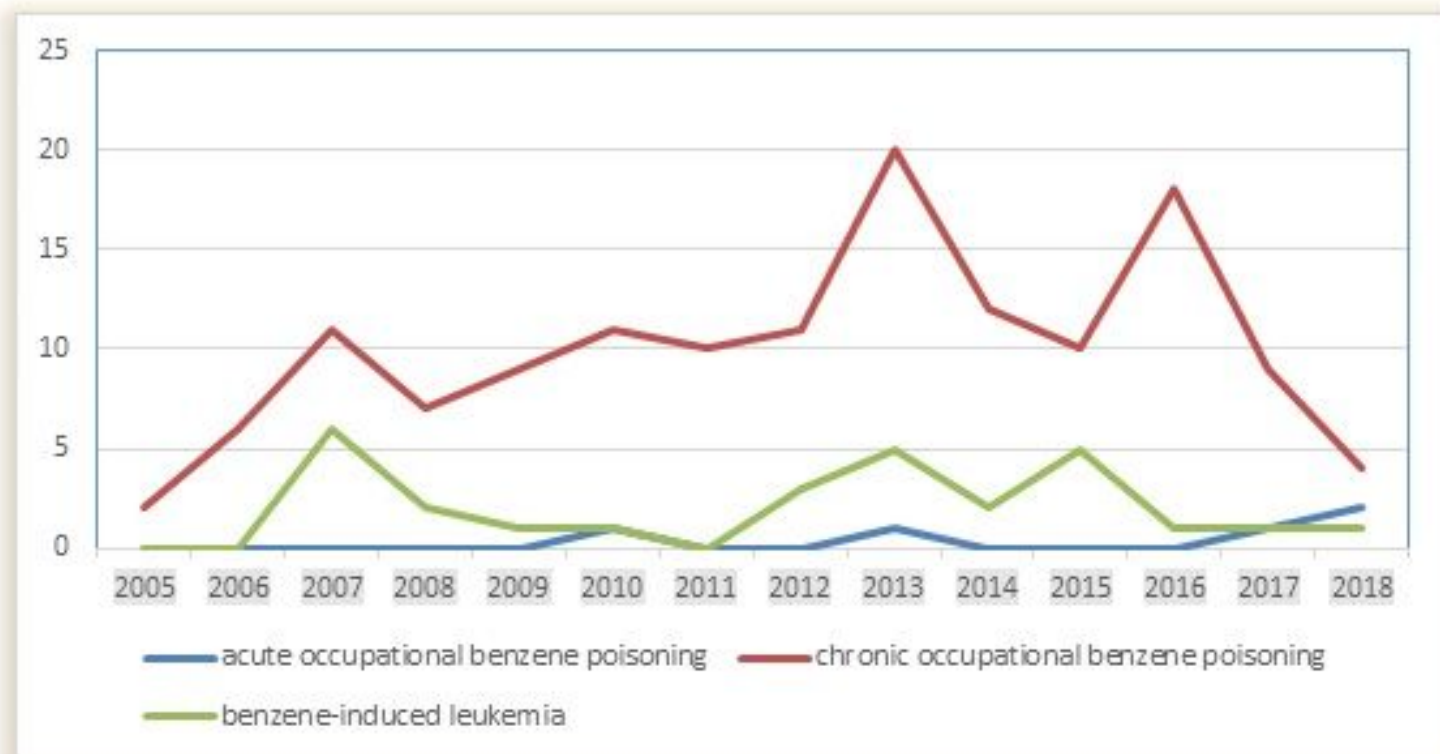

Figure 1

The cases of benzene poisoning distributed in time 


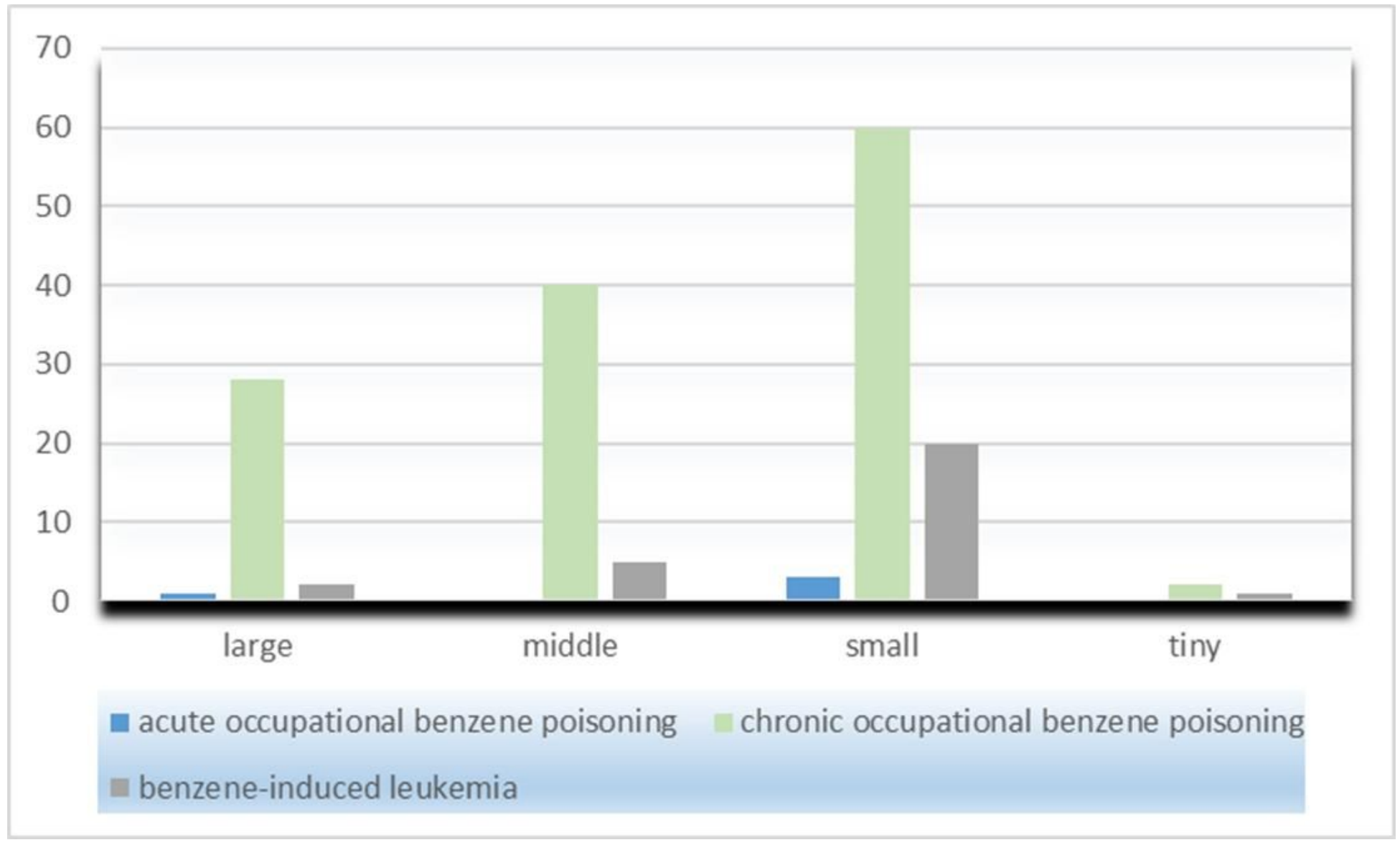

\section{Figure 2}

The cases of benzene poisoning distributed in firm size of industry 


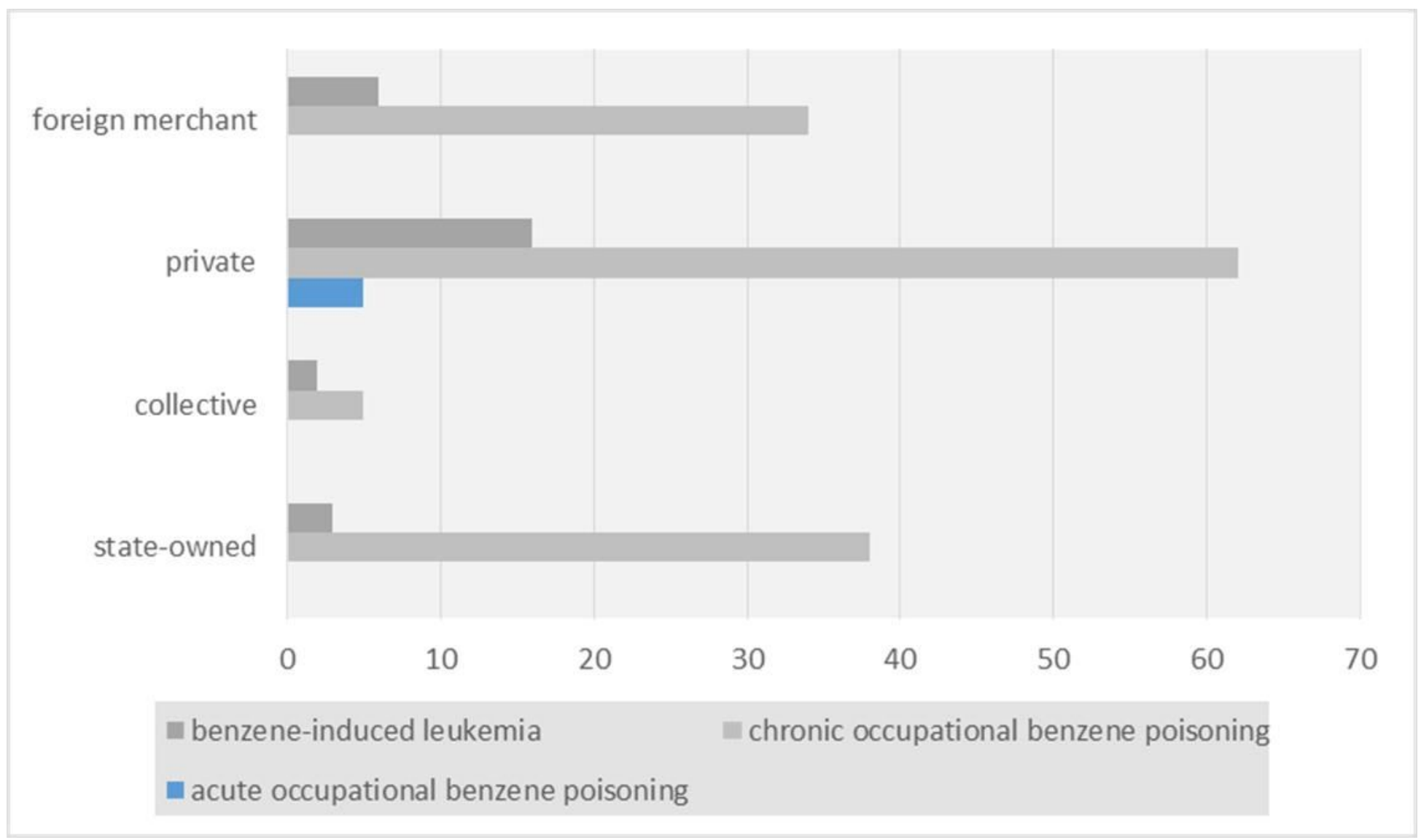

\section{Figure 3}

The cases of benzene poisoning distributed in economic type of industry 


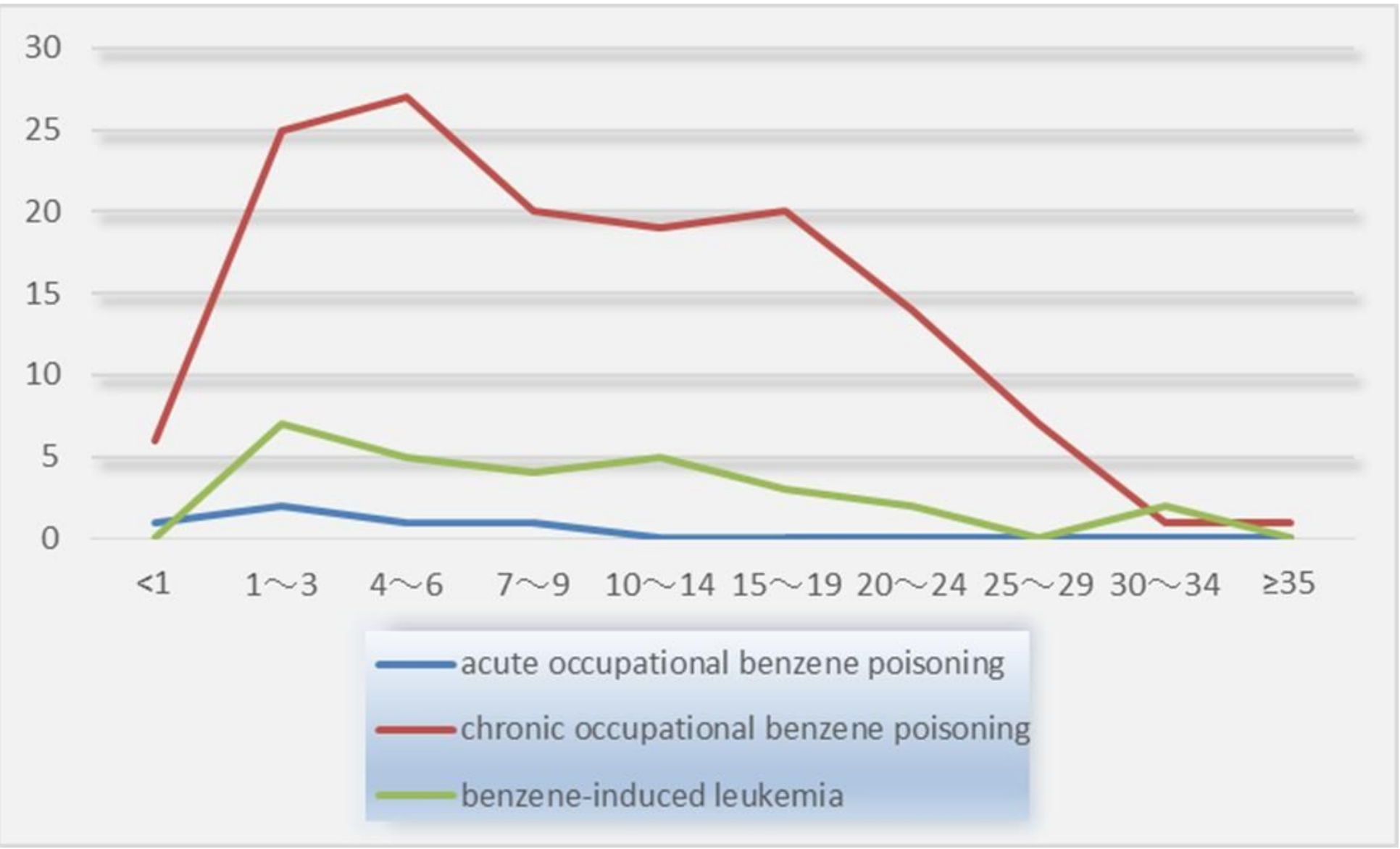

Figure 4

The cases of benzene poisoning distributed in working years 